\title{
SOCIAL AND DEMOGRAPHIC FACTORS OF PHYSICAL ACTIVITY IN 9-11-YEAR OLD SLOVENIAN CHILDREN
}

\author{
Tanja Jerina ${ }^{1}$, Rado Pišot ${ }^{2}$, and Tadeja Volmut ${ }^{3}$ \\ ${ }^{1}$ Elementary School Polhov Gradec, Polhov Gradec, Slovenia \\ ${ }^{2}$ Science and Research Centre of Koper, Institute for Kinesiology Research, Koper, Slovenia \\ ${ }^{3}$ University of Primorska, Faculty of Education, Koper, Slovenia
}

Original scientific paper

https://doi.org/10.26582/k.50.1.13

UDC: 796:314-053.5(497.12)

\begin{abstract}
:
Factors related to physical behaviour of children are important in understanding the characteristics of their physical activity. Apart from the factors of physical environment, social and demographic factors are also related to physical activity levels. Randomly selected 669 children ( $9.9 \pm 0.8$ years; $48.8 \%$ boys) from randomly selected Slovenian elementary schools participated in this study. All data were obtained during a single measurement in May 2010. The standardized questionnaire The Quality of Life Survey was used to measure physical activity (PA) levels as well as social and demographic factors that could be associated with PA. The results indicated higher PA levels in boys than in girls $(704 \pm 286 \mathrm{~min} /$ week vs. $617 \pm 268 \mathrm{~min} / \mathrm{week}$; $\mathrm{p}<.001)$. Analysis of variance confirmed higher PA levels in girls with parents of a higher socioeconomic status (SES) ( $p=.0018)$; in boys, there were no differences in PA levels according to SES ( $p=.580)$. In both the boys ( $\mathrm{p}=.047)$ and girls $(\mathrm{p}=.021)$ PA levels were higher if their whole family were members of any sport club. However, family structure was not related to PA levels in either boys $(\mathrm{p}=.648)$ or girls $(\mathrm{p}=.132)$. In boys, bi-variate regression analysis showed a positive correlation with the mother's educational level $(\mathrm{r}=.090)$, the number of children in the family $(\mathrm{r}=.150)$, the child's attitude that active commute to school is attractive $(\mathrm{r}=.108)$ and with peers' active commute to school $(\mathrm{r}=.129)$, whereas a negative correlation was obtained with fear the child would become a victim of violence or harassment on the way to school ( $\mathrm{r}=-.097)$. In girls, bi-variate regression analysis showed a positive correlation with mother's educational level ( $\mathrm{r}=.094)$, the child's attitude that active commute to school is attractive $(\mathrm{r}=.092)$ and with peers' active commute to school ( $\mathrm{r}=.221)$, whereas a negative correlation was established with fear the child would become a victim of violence or harassment on the way to school $(\mathrm{r}=-.061)$, or at recreational and sporting facilities $(\mathrm{r}=-.046)$. According to low bi-variate analysis correlations, we conclude that other factors, such as, for example, physical environment, might be strongly related to physical activity levels in children and need to be taken into account when preparing interventions for physical activity enhancement.
\end{abstract}

Key words: children, adolescents, socioeconomic status, active commute

\section{Introduction}

Physical activity (PA) plays an important role in healthy lifestyle of children and has a great impact on their health (Camero, Hobbs, Stringer, \& Taylor, 2012). Lack of PA in childhood contributes to the development of overweight and obesity (Ekelund, et al., 2006; Mark \& Janssen, 2008; Salmon, Dunstan, \& Owen, 2008; Sardinha, et al., 2008), cardiovascular disorders (McMurray, Bangdiwala, Harrell, \& Amorim, 2008), type II diabetes and metabolic syndrome (Niederer, et al., 2012; Wennberg, Gustafsson, Dunstan, Wennberg, \& Hammarström, 2013) in adulthood.
Recommendations tend to emphasize daily PA and encourage young people to accumulate a minimum of 60 minutes of daily moderateto-vigorous PA (Cavill, Biddle, \& Sallis, 2001; Klasson-Heggebø \& Anderssen, 2003; Strong, et al., 2005). Many studies indicate that PA of children and adolescents is still insufficient (Biddle, Gorely, \& Stansel, 2004; Lopes, Vasques, Maia, \& Ferreira, 2007; Roberts, Tynjala, \& Komkov, 2004; Tremblay, Boudreau-Lariviere, \& Cimon-Lambert, 2012; Volmut, Pišot, \& Šimunič, 2013). It is also known that with aging, volume and intensity of PA in childhood and adolescence are gradually 
decreasing (Lopes, et al., 2007; Sallis, Prochaska, \& Taylor, 2000; Strong, et al., 2005; Šimunič, Volmut, \& Pišot, 2010). The largest decline is detected at the start of schooling (Nyberg, Nordenfelt, Ekelund, \& Marcus, 2009; Pišot \& Simunič, 2006; Sigmund, Sigmundová, \& El Ansari, 2009; Verbestel, et al., 2011.), or at the transition from the first to the second grade of primary education (Volmut, 2014).

As public health professionals have become aware of the adverse health effects caused by the lack of PA in children and adolescents, they have begun to implement various intervention programmes to increase quantity and intensity of PA in the young. To accomplish this goal, researchers need to identify the correlates associated with decline of PA. Properly planned intervention programmes need to target these factors (Byun, Dowda, \& Pate, 2011).

Factors associated with PA of children and adolescents are classified as demographic, biological, psychological, behavioural, social, cultural and environmental (Sallis, et al., 2000). In this article, we will focus on the social and demographic factors, but we must emphasize that, when considering such an important subject, the holistic approach to the problem would be most appropriate.

Review studies from other countries show that children's PA most often positively correlates with social factors such as parents' PA (especially fathers') (Ferreira, et al., 2007; Van der Horst, Paw, Twisk, \& Van Mechelen, 2007), parents' attitude towards PA and their support (Van der Horst, et al., 2007). Adolescents' PA associates with parents (Biddle, Whitehead, O’Donovan, \& Nevill, 2005; Park \& Kim, 2008; Sallis, et al., 2000) and peers' support (Craggs, Corder, van Sluijs, \& Griffin, 2011; Park \& Kim, 2008; Van der Horst, et al., 2007), parents' PA (especially fathers') (Biddle, et al., 2005) and other family members' PA (Sallis, et al., 2000). Furthermore, dog ownership is also associated with PA levels, as some research studies have indicated a correlation between dog ownership and volume of PA, both in children and adolescents (Christian \& Trapp, 2012; Owen, et al., 2010; Salmon, Timperio, Binh, \& Veitch, 2010; Sirard, Patnode, Hearst, \& Laska, 2011).

Authors of different review studies argue that some demographic factors are significantly positively associated with children and adolescents' PA. Those demographic factors are: male gender (Biddle, et al., 2005; Craggs, et al., 2011; Park \& Kim, 2008; Sallis, et al., 2000; Stanley, Ridley, \& Dollman, 2012; Van der Horst, et al., 2007.), better SES of the family (Biddle, et al., 2005; Ferreira, et al., 2007; Park \& Kim, 2008; Stanley, et al., 2012) and higher level of parental education (Biddle, et al., 2005; Van der Horst, et al., 2007), especially mother's educational level (Ferreira, et al., 2007; Park \& Kim, 2008).
In Slovenia, only a few studies examined factors associated with PA of children and adolescents, and most of them date back to over a decade (Doupona Topič, 2005; Doupona Topič, 2010; Pišot \& Završnik, 2004; Strniša \& Planinšec, 2014). Also, the area of social and demographic factors related to PA has been less thoroughly studied. Nevertheless, we can see that PA of children and adolescents in our country relates to the following: support of the family (Doupona Topič, 2005; Pišot \& Završnik, 2004; Strniša \& Planinšec, 2014), SES (Doupona Topič, 2010; Strniša \& Planinšec, 2014), the possibility to choose from a variety of organized PA programmes (Pišot \& Zurc, 2002), age (Jelovčan, Pišot, \& Žerjal, 2002; Volmut, et al., 2013), and gender (Pišot \& Zurc, 2002; Volmut, et al., 2013; Zurc, 2008). Pišot and Završnik (2004) mentioned three factors associated with PA of primary school children: entertainment and relaxation, hanging out with friends, and parents' PA. Furthermore, Strniša and Planinšec (2014) added that PA of children, aged 7-9 years, related only to the father's PA. They also found that children's PA was associated with the level of parents' education, but not with their income, the finding also noted by Doupona Topič (2010). Several studies have reported gender differences, saying that boys are more physically active than girls (Strniša \& Planinšec, 2014; Videmšek, Videmšek, Štihec, \& Karpljuk, 2004; Volmut, 2014; Zurc, 2011; Zurc, 2012) and that they are more likely to participate in organized PA programmes (Jurak, et al., 2003; Zurc, 2011; Zurc, 2012). Many authors have found that PA of children and adolescents decreases with age (Volmut, 2014; Škof, Boben, Cecič Erpič, Zabukovec, \& Marcina, 2004; Volmut, et al., 2013; Zurc, 2011).

It is important to research both social and demographic factors to understand characteristics of PA of children and adolescents and to encourage them to pursue active lifestyle. Therefore, the purpose of this study was to determine volume of PA in 9-11-year old children in Slovenia as well as social and demographic factors that influenced it. Given the fact that not even half of children and adolescents in Slovenia reach the recommended levels of PA (Brettschneider \& Naul, 2004; Volmut, 2014) and that no study has reported on the influence of social factors on PA of children and adolescents in our country, including the simultaneous verification of multiple factors on the same sample of participants, it was necessary to conduct this type of research. Based on the study findings, efficient intervention programmes could be prepared in the future, with targeted actions aiming at enhancing both the volume and intensity of children and adolescents' PA. 


\section{Methods}

\section{Sample of participants}

The study was carried out within the framework of the research project Children's Active Travel and under the auspices of the research programme P5-038 - Kinesiology for the Quality of Life, carried out by the University of Primorska, Science and Research Centre, Institute for Kinesiology Research, and the University of Maribor, Faculty of Education. In total, 669 randomly selected children and adolescents ( $48.8 \%$ were boys) from various randomly selected Slovenian elementary schools were included in the analysis. Children in our sample were 9 to 11 years old (average age was $9.9 \pm 0.8)$.

\section{Measurement instrument}

The data were acquired using the standardized questionnaire The Quality of Life Survey (Sallis \& Owen, 2002; Sallis, et al., 2009) that was translated into the Slovenian language. In total, the questionnaire contains 158 items arranged in the following groups: general data about the child, physical activity, sedentary activities, child's active commute to and from school, technical equipment at home, shops and other public places in the home place, recreational and sports facilities in the home place, demographic data. The questionnaires were entirely completed by the participants' parents. For the needs of the study, we selected certain items (Table 1) from individual sets and included them in the analysis.

The volume of PA of an individual child was obtained from several questions, extracted from the standardized questionnaire. The calculation of PA levels included the number of Physical Education (PE) classes (How many times a week does your child have physical education?) and sport classes, meaning the additional classes of PE (How many times a week does your child attend a programme of additional physical education?) and out-of-school PA after school (How many times in the last week has your child been physically active for at least 60 minutes after school? How many times does your child attend organized group or individual PA programmes after school?) and the time the child spends for active commute to and from school (How many times a week does your child actively commute to and from school? How many minutes does your child need for active commute from your home to school?). The volume of PA is expressed in minutes a week.

The demographic factors the parents reported were school year, gender, SES, parents' educational level, structure of the family, the number of children in the family, ownership of a dog, and family membership of a sport club. SES was defined as monthly income per person in the previous year. Parents chose between the following options: a.) under $360 €$; b.) $360 €$ to $504 €$; c.) $505 €$ to $650 €$; d.) $651 €$ to $795 €$; e.) $796 €$ to $1010 €$; f.) $1011 €$ to 1300 $€$; g.) $1301 €$ to $1585 €$; h.) more than $1586 €$; and i.) $I$ don't want to answer. Parent's educational level was defined as the highest level of education completed. They chose between: a.) elementary school; b.) secondary education - vocational or technical; c.) secondary school - grammar school; d.) college; e.) higher professional education; f.) university degree; g.) master's degree; and h.) doctorate. Structure of the family was defined as: a.) a two-parent family (family with both biological parents); b.) a singleparent family (family with one biological parent); c.) reorganized family (at least one of the parents is a social, but not a biological parent); d.) extended family (family unit that consists of parents, children and other relatives, like grandparents ...).

Social factors were reported in the form of personal attitudes or assertions. With the help of a 5-point scale (Likert-type scale), namely 1 - not true at all, 2 - not true, 3 - neither untrue nor true, 4 - true, 5 - completely true, parents expressed agreement or disagreement with the following statements: a.) My child finds active commute attractive; b.) My child's peers walk/cycle to school; c.) I fear that my child would become a victim of violence or harassment on his/her way to school; d.) I fear that my child would become a victim of violence or harassment in the playground or at recreational sport facilities; e.) Ifear that my child would become a victim of violence or harassment near home; f.) There is no adult person's control in the playground or at recreational sport facilities; g.) There is no adult person's control near home; h.) There are no other children in the playground or at recreational sport facilities; i.) There are other children near home; j.) There are too many people in the playground or at recreational sport facilities; and $\mathrm{k}$.) There are too many people for physical activity near home.

\section{The process of data collecting}

Before any data collecting the principals of individual elementary schools were informed by phone about the purpose and the process of the survey. According to prior agreement with the principal, in the next step the parents' participation consent was obtained and the questionnaires were distributed to them to be filled during April and May 2011. Children and adolescents' parents filled in the questionnaires. The whole process of data collecting was carried out in compliance with the Slovenian Personal Data Protection Act, Official Gazette No. 59/1999. 


\section{Statistical analysis}

The data were processed using the statistical package SPSS, version 20.0 for Windows. Descriptive statistics was applied for the presentation of percentages, arithmetic means (M), and standard deviations (SD) for all variables. Using $t$-test the existence of any statistically significant differences was investigated in PA according to gender and family dog ownership. Analysis of variance (ANOVA) and post-hoc analysis, using Bonferroni correction test, were used to examine the differences in relation to SES, the whole family membership of a sport club, and structure of the family. Pearson's and Spearman's correlation coefficients were used to examine further whether there were any statistically significant relations between PA levels and individual social or demographic factors. ANOVA and Pearson's and Spearman's correlation coefficient analyses were conducted separately by gender. All inferences were performed at alpha set to .05 .

\section{Results}

The characteristics of the sample of participants and the average time spent in PA are presented in Table 1. Children on average dedicated $659 \pm 280$ minutes a week to PA. Boys (704 $\pm 286 \mathrm{~min} /$ week) had a higher PA level than girls (616 $\pm 268 \mathrm{~min} /$ week) $(p<.001)$. No differences were found $(p=.113)$ for dog ownership.

Tables 2 and 3 show the level of PA according to SES, family membership of sport clubs and family structure. In boys, ANOVA confirmed the differences in PA according to whether the whole families were members of sport clubs $(\mathrm{p}=.047)$. The boys from the families that were members of sport clubs were more physically active than others. SES $(\mathrm{p}=.580)$ and structure of family $(\mathrm{p}=.648)$ were not related to PA volume. In girls, ANOVA confirmed the differences in PA according to SES $(\mathrm{p}=.018)$. Post-hoc tests revealed that PA of girls differed significantly $(\mathrm{p}=.005)$ between the category under $360 €$ and the category 796 to $1010 €$. PA differences also existed according to whether the whole family was a member of a sport club $(\mathrm{p}=.021)$. The girls from the families that were sport club members were more physically active than others. Structure of family was not related to the volume of PA of girls $(\mathrm{p}=.132)$.

In Table 4 the correlation between PA levels of boys and girls and the variables of social and demographic factors are shown. In boys, PA was positively correlated with the attractiveness of active commute to children ( $\mathrm{r}=.180$ ), peers' active commute $(\mathrm{r}=.181)$, the number of children in the family $(\mathrm{r}=.147)$, and with the mothers' educational level $(\mathrm{r}=.175)$. PA was negatively correlated with the fear that the child might become a victim of
Table 1. Characteristics of the sample of participants

\begin{tabular}{|c|c|}
\hline & TOTAL \\
\hline Physical activity (M $\pm S D ;$ min/week) & $659.7 \pm 280.2$ \\
\hline Age (M士SD; years) & $9.9 \pm 0.8$ \\
\hline \multicolumn{2}{|l|}{ Gender (\%) } \\
\hline Boys & 48.8 \\
\hline Girls & 51.2 \\
\hline \multicolumn{2}{|l|}{ Socioeconomic status (monthly income) (\%) } \\
\hline Under $360 €$ & 14.6 \\
\hline 361 to $504 €$ & 19.7 \\
\hline 505 to $650 €$ & 10.6 \\
\hline 651 to $795 €$ & 10.2 \\
\hline 796 to $1010 €$ & 8.7 \\
\hline 1011 to $1300 €$ & 4.9 \\
\hline 1301 to $1585 €$ & 1.6 \\
\hline More than $1586 €$ & 1.6 \\
\hline Do not want to answer & 28.1 \\
\hline \multicolumn{2}{|l|}{ Mother's/father's educational level (\%) } \\
\hline Elementary school & $9.0 / 9.6$ \\
\hline Secondary school (vocational or technical) & $42.2 / 59.4$ \\
\hline Secondary school (grammar school) & $12.3 / 11.1$ \\
\hline College & $9.5 / 5.1$ \\
\hline Higher professional education & $9.2 / 3.9$ \\
\hline University degree & $15.3 / 8.1$ \\
\hline Master's degree & $2.0 / 2.0$ \\
\hline Doctorate & $0.5 / 0.8$ \\
\hline \multicolumn{2}{|l|}{ Family structure (\%) } \\
\hline Two-parent family & 81.1 \\
\hline Single-parent family & 9.1 \\
\hline Reorganized family & 2.3 \\
\hline Extended family & 7.5 \\
\hline Number of children in the family $(M \pm S D)$ & $2.2 \pm 0.9$ \\
\hline \multicolumn{2}{|l|}{ Dog ownership (\%) } \\
\hline Yes & 43.2 \\
\hline No & 56.8 \\
\hline \multicolumn{2}{|l|}{ Family membership of a sport club (\%) } \\
\hline Yes & 19.0 \\
\hline No & 81.0 \\
\hline Do not know & 0 \\
\hline \multicolumn{2}{|l|}{ Social factors: } \\
\hline$A C$ is attractive for the child & $1.8 \pm 1.3$ \\
\hline Child's peers walk/cycle to school & $2.4 \pm 1.7$ \\
\hline $\begin{array}{l}\text { Parents' fear the child would become a victim } \\
\text { of violence, harassment on AC }\end{array}$ & $2.4 \pm 1.4$ \\
\hline $\begin{array}{l}\text { Parents' fear the child would become a victim } \\
\text { of violence, harassment in the playground or } \\
\text { at RSF }\end{array}$ & $2.1 \pm 1.3$ \\
\hline $\begin{array}{l}\text { Parents' fear the child would become a victim } \\
\text { of violence, harassment near home }\end{array}$ & $2.0 \pm 1.3$ \\
\hline $\begin{array}{l}\text { No adult person's control in the playground } \\
\text { or at RSF }\end{array}$ & $2.4 \pm 1.4$ \\
\hline No adult person's control near home & $2.3 \pm 1.5$ \\
\hline No other children in the playground or at RSF & $1.8 \pm 1.1$ \\
\hline No other children near home & $2.0 \pm 1.3$ \\
\hline To many people in the playground or at RSF & $1.7 \pm 1.1$ \\
\hline Too many people near home & $1.6 \pm 1.0$ \\
\hline
\end{tabular}

AC - active commute; RSF - recreational sport facilities

Results related to social factors refer to the answers on a 5-point Likert-type scale (1-not true at all, 2-not true, 3-neither untrue nor true, 4-true, 5-completely true) 
Table 2. Physical activity level of boys according to socioeconomic status (SES), family membership of sports clubs, and family structure

\begin{tabular}{|c|c|c|}
\hline & $\begin{array}{l}\text { Physical activity } \\
\text { (min/week) }\end{array}$ & \\
\hline & $\mathrm{M} \pm \mathrm{SD}$ & $p$ \\
\hline $\begin{array}{l}\text { Socioeconomic status } \\
\text { (monthly income) }\end{array}$ & & .580 \\
\hline $\begin{array}{l}\text { Under } 360 € \\
361 \text { to } 504 € \\
505 \text { to } 650 € \\
651 \text { to } 795 € \\
796 \text { to } 1010 € \\
1011 \text { to } 1300 € \\
1301 \text { to } 1585 € \\
\text { More than } 1586 € \\
\text { Do not want to answer }\end{array}$ & $\begin{array}{c}677 \pm 366 \\
698 \pm 322 \\
671 \pm 271 \\
720 \pm 251 \\
741 \pm 323 \\
877 \pm 253 \\
817 \pm 188 \\
570 \pm 42,4 \\
710 \pm 278\end{array}$ & \\
\hline $\begin{array}{l}\text { Family membership of a } \\
\text { sport club }\end{array}$ & & $.047^{*}$ \\
\hline $\begin{array}{l}\text { Yes } \\
\text { No } \\
\text { Do not know }\end{array}$ & $\begin{array}{c}765 \pm 256 \\
687 \pm 291 \\
0\end{array}$ & \\
\hline Family structure & & .648 \\
\hline $\begin{array}{l}\text { Two-parent family } \\
\text { Single-parent family } \\
\text { Reorganized family } \\
\text { Extended family }\end{array}$ & $\begin{array}{l}714 \pm 280 \\
655 \pm 264 \\
781 \pm 386 \\
709 \pm 285\end{array}$ & \\
\hline
\end{tabular}

Table 3. Physical activity level of girls according to socioeconomic status (SES), family membership of sports clubs, and family structure

\begin{tabular}{|c|c|c|}
\hline & $\begin{array}{l}\text { Physical activity } \\
\text { (min/week) }\end{array}$ & \\
\hline & $\mathrm{M} \pm \mathrm{SD}$ & $p$ \\
\hline $\begin{array}{l}\text { Socioeconomic status } \\
\text { (monthly income) }\end{array}$ & & $.018^{*}$ \\
\hline $\begin{array}{l}\text { Under } 360 € \\
361 \text { to } 504 € \\
505 \text { to } 650 € \\
651 \text { to } 795 € \\
796 \text { to } 1010 € \\
1011 \text { to } 1300 € \\
1301 \text { to } 1585 € \\
\text { More than } 1586 € \\
\text { Do not want to answer }\end{array}$ & $\begin{array}{l}501 \pm 185^{a} \\
650 \pm 309 \\
581 \pm 245 \\
660 \pm 282 \\
749 \pm 211^{a} \\
574 \pm 202 \\
701 \pm 141 \\
578 \pm 169 \\
623 \pm 292\end{array}$ & \\
\hline $\begin{array}{l}\text { Family membership of a } \\
\text { sport club }\end{array}$ & & $.021^{*}$ \\
\hline $\begin{array}{l}\text { Yes } \\
\text { No } \\
\text { Do not know }\end{array}$ & $\begin{array}{c}689 \pm 292 \\
600 \pm 260 \\
0\end{array}$ & \\
\hline Family structure & & .132 \\
\hline $\begin{array}{l}\text { Two-parent family } \\
\text { Single-parent family } \\
\text { Reorganized family } \\
\text { Extended family }\end{array}$ & $\begin{array}{l}624 \pm 261 \\
623 \pm 322 \\
745 \pm 407 \\
516 \pm 224\end{array}$ & \\
\hline
\end{tabular}

${ }^{*} p<.05$; a Significantly different after Bonferroni correction $(p=.005)$

Table 4. Correlation between physical activity of boys and girls and demographic and social factors

\section{Age}

Number of children in the family

The child finds active commute to school attractive

Child's peers actively commute to school

Fear the child would become a victim of violence or harassment on the way to school

Fear the child would become a victim of violence or harassment at recreational and sporting facilities

Fear the child would become a victim of violence or harassment near home

No adult person's control at recreational and sporting facilities

No adult person's control near home

No other children at recreational and sporting facilities

No other children near home

Too many people at recreational and sporting facilities

Too many people near home
Physical activity

Pearson's correlation coefficient

\begin{tabular}{cc}
\hline Boys & Girls \\
-.057 & .016 \\
$.147^{* *}$ & -.038 \\
$.180^{* *}$ & $.135^{*}$ \\
$.181^{* *}$ & $.213^{* *}$ \\
$-.147^{* *}$ & $-.118^{*}$ \\
.002 & $-.121^{*}$ \\
-.036 & -.093 \\
-.001 & -.069 \\
-.037 & -.028 \\
-.005 & -.097 \\
-.013 & -.042 \\
-.008 & -.030 \\
-.051 & -.005 \\
\hline Spearman's rank \\
correlation coefficient \\
\hline Boys & Girls \\
\hline $.175^{* *}$ & $.113^{*}$ \\
.081 & .067 \\
\hline
\end{tabular}

's educational leve

Father's educational level

${ }^{*} p<.05 ;{ }^{* *} p<.01$ 
violence or harassment on his/her way to school $(\mathrm{r}=-.147)$. In girls, PA was positively correlated with the attractiveness of active commute to children $(\mathrm{r}=.135)$, peers' active commute $(\mathrm{r}=.213)$, and with the mothers' educational level ( $\mathrm{r}=.113)$. PA was negatively correlated with the fear that the child might become a victim of violence or harassment on his/her way to school $(\mathrm{r}=-.118)$ or at recreational sporting facilities $(\mathrm{p}=-.121)$. Those bi-variate correlations explain only a small portion of PA variance by the observed independent variables (from 1.3 to $4.5 \%$ ).

\section{Discussion and conclusions}

This study provides a new evidence adding to the existing literature on social and demographic correlates of physical activity in Slovenian children. The results show that children and adolescents are physically active 94.2 minutes a day on average, which means the participants attain sufficient volume of PA. These results do not match the results of the study by Guthold, Cowan, Autenrieth, Kann, and Riley (2010), where the results of 72,845 children from 34 countries show that only few participants ( $23.8 \%$ boys and $15.4 \%$ girls) attain sufficient volume of PA. Results of the studies using objective measurement methods indicate that children and adolescents in Slovenia (Volmut, et al., 2013) and in the world (Cavill, et al., 2001; Ekelund, Tomkinson, \& Armstrong, 2011; Klasson-Heggebø, \& Anderssen, 2003; Strong, et al., 2005; Troiano, et al., 2008) do not reach the recommended 60-minute daily volume of moderate-to-vigorous PA.

Boys are slightly more engaged in physical activities than girls, which has also been proven by most of other studies (Ammouri, Kaur, Neuberger, Gajewski, \& Choi, 2007; Jurak, et al., 2003; Pišot \& Zurc, 2002; McKenzie, et al., 1997; Sallis, et al., 2000; Volmut, et al., 2013; Zurc, 2008). Some authors also found that boys were more frequently engaged in high-intensity PA and participated in sport competitions more often than girls (Garcia, Pender, Antonakos, \& Ronis, 1998; McKenzie, et al., 1997), which could be a reason for a larger volume of PA in boys.

We have found no correlation between the volume of PA of children and adolescents and dog ownership. The results of other studies, which examined this correlation, are different. Some authors have found that dog ownership positively correlates with medium-to-high PA (Owen, et al., 2010; Salmon, et al., 2010), but others only indicate a positive correlation between dog ownership and the volume of PA in general (Christian, \& Trapp, 2012; Sirard, et al., 2011). For clearer results, it would be necessary to focus on factors that could potentially moderate the association between physical activity and dog ownership, such as age of children, size and breed of the dog, home and neighbourhood environ- ments and the role of family members in walking or actively playing with the dog.

The differences in the volume of PA according to SES were found only in girls. The least physically active are those whose parents have the lowest monthly income, which coincides with the results of the study by Seabra et al. (2013), who also found differences in the volume of PA according to SES in girls only. Many reviews also show a link between PA and SES, but the results are divergent. Sallis et al. (2000) could not find such a link in most of the reviewed studies, whereas Ferreira et al. (2007) discovered a link between PA and mother's educational level, but there was no link between PA and the education of both parents or father's occupation. Further, Biddle et al. (2005) reported a relation between PA of girls and family income, but not so with parents' educational level. The reviews' results are inconsistent mainly because of different definitions of SES in each study (as educational level of one or both parents, their occupation, and/ or income). At the same time, many studies do not include measurements of all forms of PA, but only of the organized ones. Thus, Macintyre and Mutrie (2004) argue that SES does not influence the total volume of PA since, despite being included in the organized PA, children who live in families with a higher SES do not take part in the unorganized forms of PA, due to which their total energy consumption is the same as that of children from families with a lower SES.

Interestingly, girls in our study, whose parents have the highest monthly income, are not the most physically active ones; they immediately followed those whose parents have the lowest monthly income. These findings suggest that the organized leisure PA programmes are not free of charge, therefore, families with a higher monthly income can allocate more money for additional sports equipment and various devices, thus additionally motivating children for engagement in PA. Families with a higher SES usually live in areas where the offer of leisure PA programmes for children and adolescents is manifold and more variegated, because of which also PA of children and adolescents is higher (Cradock, Melly, Allen, Morris, \& Gortmaker, 2009). At the same time, these families have more opportunities to spend holidays in a physically active way, for which period otherwise a decrease in the volume and intensity of PA of children is characteristic (Šimunič, 2008; Volmut, 2014). Simultaneously, the children whose parents have a higher income also have broad access to different electronic media (Roberts \& Foehr, 2008) that stimulate their sedentary behaviour. This might be the reason why the results of our research show the children whose parents have the highest income rank the second last on the physical activity scale.

The results also indicate that the children whose family are members of sport clubs are more 
physically active. Many studies show that parents' support and family behaviour style are important factors with a positive influence on the volume of PA of children and adolescents (Biddle, et al., 2005; Davison, et al., 2012; Doupona Topič, 2005; Napier, Brown, Werner, \& Gallimore, 2011; Sallis, et al., 2000; Veitch, Hume, Salmon, Crawford, \& Ball, 2011; Welk, Wood, \& Morrs, 2003). The whole family membership of a sport club could be understood as a kind of such support. The review study which examines the correlation between parents and children's PA levels show mixed results - only six of 14 studies indicated that parental PA was a moderate predictor of children's PA, but seven studies did not support these findings (Gustafson $\&$ Rhodes, 2006). Authors highlight that there are many covariates, which can influence this association.

The bi-variate regression analysis shows in both boys and girls that mother's educational level positively correlates with children's PA. Correlation with parents' educational level (Biddle, et al., 2005; Strniša \& Planinšec, 2014; Van der Horst, et al., 2007), especially mothers' (Ferreira, et al., 2007; Park \& Kim, 2008), is shown also in many other studies. Mother's educational level is crucial because of the role the mother plays in the nurture of children. Mother does not only take care that child's material and physical needs are satisfied, but also take care of his/her emotional, psychological, and intellectual development (Shaw, 2008). Thus, we can conclude that mothers with a higher educational level, who know positive effects of PA on health, transfer this to their children.

In both boys and girls, physical activity positively correlates with the fact that a child finds active commute to school attractive and that the other child(ren) in the family actively commutes to school, whereas it negatively correlates with the fear that, on the way to school, the child could become a victim of violence or harassment. Interestingly, all these factors are linked to active commute to school, which has not been detected in other studies. Given that an increasing number of studies have highlighted great contribution of active commute to volume and intensity of PA (Jerina \& Pišot, 2014), this does not come as a surprise.

Physical activity of boys also positively correlates with the number of children in family. Hardy et al. (2006) have indicated that interaction with siblings has a significant impact on the development and behaviour of children and adolescents. This could be associated with boys' play, which is more peer-directed and guided by the peer (brothers) group. It is known that boys' play tends to be more physically active than girls' play (Berenbaum, Martin, Hanish, Briggs, \& Fabes, 2007). However, this is hard to be associated with the results of our research, because we cannot argue about the gender of other children in families.
At the end, PA of girls negatively correlates with the fear that, at the recreational and sports facilities, the girl could become a victim of violence or harassment. We can believe that this fear is more girl-related, since it is known that girls are overwhelmingly victimized due to their gender (Dunne, Humphreys, \& Leach, 2004).

In conclusion, the review and the study of demographic factors and primarily of the factors of social environment related to the volume of children and adolescents' PA in Slovenia has an important role in designing intervention programmes in the future. To date we have not traced any similar study in our country that would simultaneously deal with several factors of this kind on the same sample of participants. Nevertheless, our study has several limitations.

First, the volume of PA in our study was estimated in a subjective way, using a survey questionnaire. Therefore, the results differ from the results that would have been obtained by objective methods, such as accelerometer or step counter. Survey questionnaires can cover a portion of population, but their disadvantage is their extensiveness, which leads to incorrect answers and large estimation errors of physical activity levels, because of excessive time lag between PA and its verification (Šimunič, et al., 2010; Škof, 2010). Furthermore, for identifying PA correlates, we translated a standardised questionnaire; however, we did not re-validate the translated version. However, we strongly believe the data are valid. Our belief is based upon high return rate, no complaints, and no out-of-scope answers.

Second, with the interpretation of individual factors certain differences appear with regard to other studies, especially with the factor of SES. We have defined SES as a monthly income per person in the family (parents' educational level was addressed separately), while in some other studies (Biddle, et al., 2005; Ferreira, et al., 2007) SES was defined in a different way, namely as a combination of family income and parents' educational level and/or their occupation.

At the end, we found that the selected determinants have a very little effect on children's PA levels. There might be several reasons for these results. Perhaps the variables were not selected carefully enough, or they were not potential predictors of children's PA in our area, which was a large limitation. On the other hand, we can conclude that social environment has a small effect on children and adolescents' PA and it is necessary to look for other factors that influence it. In the future, it would be reasonable to consider several factors, including social and physical environment, demographic factors and policy, operating on several levels, in accordance with the existing ecological models (Stokols, 1992). 


\section{References}

Ammouri, A.A., Kaur, H., Neuberger, G.B., Gajewski, B., \& Choi, W.S. (2007). Correlates of exercise participation in adolescents. Public Health Nursing, 24(2), 111-120.

Berenbaum, S.A., Martin, C.L., Hanish, L.D., Briggs, P.T., \& Fabes, R.A. (2007). Sex differences in childrens' play. In J.B. Becker (Eds.), Sex differences in the brain, from genes to behavior (pp. 275-281). New York: Oxford University Press.

Biddle, S.J., Gorely, T., \& Stensel, D.J. (2004). Health-enhancing physical activity and sedentary behaviour in children and adolescents. Journal of Sport Sciences, 22(8), 679-701.

Biddle, S.J.H., Whitehead, S.H., O’Donovan, T.M., \& Nevill, M.E. (2005). Correlates of participation in physical activity for adolescent girls: A systematic review of recent literature. Journal of Physical Activity and Health, 2(4), 423-434.

Brettschneider, W.D., \& Naul, R. (2004). Study on young people's lifestyles and sedentariness and the role of sport in the context of education and as a means of restoring the balance. Final report. Retrieved December 22, 2010 from: http://ec.europa.eu/sport/library/doc/c1/doc374 en.pdf

Byun, W., Dowda, M., \& Pate, R.R. (2011). Correlates of objectively measured sedentary behavior in US preschool children. Pediatrics, 128(5), 937-945.

Camero, M., Hobbs, C., Stringer, M., Branscum, P., \& Taylor, L. (2012). A review of physical activity interventions on determinants of mental health in children and adolescents. International Journal of Mental Health Promotion, 14, 196-206.

Cavill, N., Biddle, S., \& Sallis, J.F. (2001). Health enhancing physical activity for young people: Statement of the United Kingdom expert consensus conference. Pediatric Exercise Science, 13(1), 12-25.

Christian, H., \& Trapp, G. (2012). Understanding the relationship between dog ownership and children's physical activity and sedentary behaviour. Journal of Science and Medicine in Sport, 15(S265-S327), 663.

Cradock, A.L., Melly, S.J., Allen, J.G., Morris, J.S., \& Gortmaker, S.L. (2009). Youth destinations associated with objective measures of physical activity in adolescents. Journal of Adolescent Health, 45(3 Suppl), S91-S98.

Craggs, C., Corder, K., van Sluijs, E.M.F., \& Griffin, S.J. (2011). Determinants of change in physical activity in children and adolescents: A systematic review. American Journal of Preventive Medicine, 40(6), 645-658.

Davison, K.K., Nishi, A., Kranz, S., Wyckoff, L., May, J.J., Earle-Richardson, G.B., et al. (2012). Associations among social capital, parenting for active lifestyles, and youth physical activity in rural families living in upstate New York. Social Science and Medicine, 75(8), 1488-1496.

Doupona Topič, M. (2005). Sport, gender and the issues of life. In K.D. Gilbert (Ed.), Sexuality, sport and the culture of risk (pp. 103-108). Oxford: Meyer \& Meyer Sport.

Doupona Topič, M. (2010). Vpliv socialne stratifikacije na značilnosti športno rekreativne dejavnosti v Sloveniji. [The impact of social stratification on characteristics of recreational sports and physical activities in Slovenia. In Slovenian.] Šport, 58(1-2), 100-104.

Dunne, M., Humphreys, S., \& Leach, F. (2004). Gender and violence in schools. Background paper prepared for the Education for All: The Leap to Equality. Paper commissioned for the EFA global monitoring report 2003/4. UNESCO. Retrieved July 10, 2017 from: http://unesdoc.unesco.org/images/0014/001467/146763e.pdf

Ekelund, U., Brage, S., Froberg, K., Harro, M., Anderssen, S.A., Sardinha, L.B., et al. (2006). TV viewing and physical activity are independently associated with metabolic risk in children: The European Youth Heart Study. PLoS Med, 3(12), 488.

Ekelund, U., Tomkinson, G., \& Armstrong, N. (2011). What proportion of youth are physically active? Measurement issues, levels and recent time trends. British Journal of Sports Medicine, 45(11), 859-865.

Ferreira, I., Van der Horst, K., Wendel-Vos, W., Kremers, S., van Lenthe, F.J., \& Brug, J. (2007). Environmental correlates of physical activity in youth - A review and update. Obesity Reviews, 8(2), 129-154.

Garcia, A.W., Pender, N.J., Antonakos, C.L., \& Ronis, D.L. (1998). Changes in physical activity beliefs and behaviors of boys and girls across the transition to junior high school. Journal of Adolescent Health, 22(5), 394-402.

Gustafson, S.L., \& Rhodes, R.E. (2006). Parental correlates of physical activity in children and early adolescents. Sports Medicine, 36(1), 79-97.

Guthold, R., Cowan, M.J., Autenrieth C. S., Kann, L., \& Riley, L.M. (2010). Physical activity and sedentary behavior among schoolchildren: A 34-country comparison. Journal of Pediatrics, 157(1), 43-49.

Hardy, L.L., Baur, L.A., Garnett, S.P., Crawford, D., Campbell, K.J., Shrewsbury, V.A., et al. (2006). Family and home correlates of television viewing in 12-13-year old adolescents: The Nepean Study. International Journal of Behavioral Nutrition and Physical Activity, 3, 24.

Jelovčan, G., Pišot, R., \& Žerjal, I. (2002). Ukvarjanje s prostočasno gibalno/športno aktivnostjo otrok v zgodnjem šolskem obdobju. [Participation in leisure physical/sports activity of children in early school age. In Slovenian.] In R. Pišot, V. Štemberger, F. Krpač \& T. Filipčič. (Eds.), $2^{\text {nd }}$ International Science and Expert Symposium A child in motion - Proceedings (pp. 580-585). Ljubljana: Univerza v Ljubljani, Pedagoška fakulteta.

Jerina, T., \& Pišot, R. (2014). Doprinos aktivne poti v šoli k celostni gibalni/športni aktivnosti otrok in mladostnikov: Pregledni prispevek. [The contribution of active commute to school to overall physical activity level in children and adolescents: A review article. In Slovenian.] Revija za elementarno izobraževanje, 1, 47-64. 
Jurak, G., Kovač, M., Strel, J., Starc, G., Majerič, M., Filipčič, T., et al. (2003). Gender differences of Slovenian children and youth in spending summer holidays. In Suomen liikuntalääketiede [Finnish sports and exercise medicine]: The International XVII Puijo Symposium; special issue: Physical Activity and Health: Gender Differences Across the Lifespan. Retrieved October 10, 2003 from: http://ffp.uku.fi/sll/index.html

Klasson-Heggebø, L., \& Anderssen, S.A. (2003). Gender and age differences in relation to the recommendation of physical activity among Norwegian children and youth. Scandinavian Journal of Medicine and Science in Sports, 13(5), 293-298.

Lopes, V.P., Vasques, C.M., Maia, J.A., \& Ferreira, J.C. (2007). Habitual physical activity levels in childhood and adolescence assessed with accelerometery. Journal of Sports Medicine and Physical Fitness, 47(2), $217-222$.

Macintyre, S., \& Mutrie, N. (2004). Socioeconomic differences in cardiovascular disease and physical activity: Stereotypes and reality. Journal of the Royal Society for the Promotion of Health, 124(2), 66-69.

Mark, A.E., \& Janssen, I. (2008). Relationship between screen time and metabolic syndrome in adolescents. Journal of Public Health, 30(2), 153-160.

McKenzie, T.L., Sallis, J.F., Elder, J.P., Berry, C.C., Hoy, P.L., Nader, P.R., et al. (1997). Physical activity levels and prompts in young children at recess: A two-year study of a bi-ethic sample. Research Quarterly for Exercise and Sport, 68(3), 195-202.

McMurray, R.G., Bangdiwala, S.I., Harrell, J.S., \& Amorim, L.D. (2008). Adolescents with metabolic syndrome have a history of low aerobic fitness and physical activity levels. Dynamic Medicine, 7, 5.

Napier, M.A., Brown, B.B., Werner, C.M., \& Gallimore, J. (2011). Walking to school: Community design and child and parent barriers. Journal of Environmental Psychology, 31(1), 45-51.

Niederer, I., Kriemler, S., Zahner, L., Burgi, F., Ebenegger, V., Marques-Vidal, P., et al. (2012). BMI group-related differences in physical fitness and physical activity in preschool-age children: A cross-sectional analysis. Research Quarterly for Exercise and Sport, 83, 12-19.

Nyberg, G.A., Nordenfelt, A.M., Ekelund, U., \& Marcus, C. (2009). Physical activity patterns measured by accelerometry in 6- to 10-yr-old children. Medicine and Science in Sports and Exercise, 41(10), 1842-1848.

Owen, C.G., Nightingale, C.M., Rudnicka, A.R., Ekelund, U., McMinn, A.M., van Sluijs, E.M.F., et al. (2010). Family dog ownership and levels of physical activity in childhood: Findings of the Child Heart and Health Study in England (CHASE). American Journal of Public Health, 100(9), 1669-1671.

Park, H., \& Kim, N. (2008). Predicting factors of physical activity in adolescents: A systematic review. Asian Nursing Research, 2(2), 113-128.

Pišot, R., \& Šimunič, B. (2006). Vloga biomehanskih lastnosti skeletnih mišic v gibalnem razvoju otrok. [The role of biomechanical characteristics of skeletal muscles in child motor development. In Slovenian.] Koper: Založba Annales, Univerza na Primorskem, Znanstveno-raziskovalno središče, Inštitut za kineziološke raziskave.

Pišot, R., \& Završnik, J. (2004). Analiza razlogov za ukvarjanje z gibalno/športno aktivnostjo osnovnošolskih otrok. [Analysis of the reasons for participation in physical/sports activity of elementary school aged children. In Slovenian.] In R. Pišot, V. Štemberger, J. Zurc \& A. Obid (Eds.), Otrok v gibanju: 3. mednarodni simpozij (pp. 41-42). Koper: Univerza na Primorskem, Znanstveno-raziskovalno središče Koper.

Pišot, R., \& Zurc, J. (2002). Ponudba interesnih gibalnih/športnih aktivnosti na osnovnih šolah v Gorenjski regiji. [Offer of leisure time physical/sports activities at elementary schools in Gorenjska region. In Slovenian.] In M. Kovač \& B. Škof (Eds.), Razvojne smernice športne vzgoje: zbornik prispevkov posvet športnih pedagogov (pp. 353-359). Ljubljana: Zveza društev športnih pedagogov Slovenije.

Roberts, D.F., \& Foehr, U.G. (2008). Trends in media use. The Future of Children, 18(1), 11-37.

Roberts, C., Tynjala, J., \& Komkov, A. (2004). Physical activity. In C. Currie, C. Roberts, A. Morgan, et al. (Eds.), Young people's health in context. Health Behaviour in School-aged Children (HBSC) study. International report from 2001/2002 survey (pp. 90-97). Copenhagen: World Health Organization.

Sallis, J.F., \& Owen, N. (2002). Ecological models of health behavior. In K. Glanz, B.K. Rimer \& F.M. Lewis (Eds.), Health behavior and health education: Theory, research, and practice ( $3^{\text {rd }}$ ed.; pp. 462-484). San Francisco: Jossey-Bass.

Sallis, J.F., Prochaska, J.J., \& Taylor, W.C. (2000). A review of correlates of physical activity of children and adolescents. Medicine and Science in Sports and Exercise, 32(5), 963-975.

Sallis, J.F., Saelens, B.E., Frank, L.D., Conway, T.L., Slymen, D.J., Cain, K.L., et al. (2009). Neighborhood built environment and income: Examining multiple health outcomes. Social Science and Medicine, 68, 1285-1293.

Salmon, J., Dunstan, D., \& Owen, N. (2008). Should we be concerned about children spending extended periods of time in sedentary pursuits even among the highly active? International Journal of Pediatric Obesity, 3(2), 66-68.

Salmon, J., Timperio, A., Binh, C., \& Veitch, J. (2010). Dog ownership, dog walking and children's and parents' physical activity. Research Quarterly for Exercise and Sport, 81(3), 264-271.

Sardinha, L.B., Bo Andersen, L., Anderssen, S.A., Quiterio, A.L., Ornelas, R., Froberg, K., et al. (2008). Objectively measured time spent sedentary is associated with insulin resistance independent of overall and central body fat in 9-to-10-year-old Portuguese children. Diabetes Care, 31(1), 569-575. 
Seabra, A.C., Seabra, A.F., Mendonça, D.M., Brustad, R., Maia, J.A., Fonseca, A.M., et al. (2013). Psychosocial correlates of physical activity in school children aged 8-10 years. European Journal of Public Health, 23(5), 794-798.

Shaw, S.M. (2008). Family leisure and changing ideologies of parenthood. Sociology Compass, 2(2), 688-703.

Sigmund, E., Sigmundová, D., \& El Ansari, W. (2009). Changes in physical activity in preschoolers and first-grade children: Longitudinal study in the Czech Republic. Child Care Health Development, 35(3), 376-382.

Sirard, J.R., Patnode, C.D., Hearst, M.O., \& Laska, M.N. (2011). Dog ownership and adolescent physical activity. American Journal of Preventive Medicine, 40(3), 334-337.

Stanley, R.M., Ridley, K., \& Dollman, J. (2012). Correlates of children's time-specific physical activity: A review of the literature. International Journal of Behavioral Nutrition and Physical Activity, 9(50).

Stokols, D. (1992). Establishing and maintaining healty environments: Toward a social ecology of health promotion. The American Psychologist, 47(1), 6-22.

Strniša, K., \& Planinšec, J. (2014). Gibalna dejavnost otrok z vidika socialnoekonomskih razsežnosti. [Childrens' physical activity in the light of socio-economic dimensions. In Slovenian.] Revija za elementarno izobraževanje, 7(1), 99-107.

Strong, W.B., Malina, R.M., Blimke, C.J., Daniels, S.R., Dishman, R.K., Gutin, B., et al. (2005). Evidence-based physical activity for school-age youth. Journal of Pediatrics, 146(6), 732-737.

Šimunič, B. (2008). Otrok med vplivi sodobnega življenjskega sloga - gibalne sposobnosti, telesne značilnosti in zdravstveni status slovenskih otrok. [Children amidst influences of modern lifestyle - motor abilities, physical characteristics and health status of Slovenian children. In Slovenian.] Koper: Univerza na Primorskem, Znanstveno-raziskovalno središče Koper, Inštitut za kineziološke raziskave. Retrieved April 20, 2014 from: http://www.mizs.gov.si/fileadmin/mizs.gov.si/pageuploads/podrocje/razvoj_solstva/crp/2008/crp_V5_0232_ porocilo.pdf

Šimunič, B., Volmut, T., \& Pišot, R. (2010). Pomen optimizacije gibanja otrok: znanstveno podprta moderna izhodišča. [The importance of optimizing moving in children: Scientifically supported modern platform. In Slovenian.] In J. Dolinšek (Ed.), Otrok in šport. Obravnava otrok z drisko. Šokovna stanja v otroškem obdobju (pp. 43-47). Maribor: Univerzitetni klinični center, Klinika za pediatrijo.

Škof, B. (2010). Spravimo se v gibanje - za zdravje in srečo gre. [Let's move - it is about health and happiness. In Slovenian.] Ljubljana: Univerza v Ljubljani, Fakulteta za šport.

Škof, B., Boben, D., Cecić Erpič, S., Zabukovec, V., \& Marcina, P. (2004). Vpliv starosti, spola in šolskega okolja mladostnikov na njihova stališča do športne aktivnosti. [Influence of adolescents' age, gender and school environment on their attitudes towards physical activity. In Slovenian.] In R. Pišot, V. Štemberger, J. Zurc \& A. Obid (Eds.), Otrokv gibanju: zbornik prispevkov: 3. mednarodni simpozij = A child in motion: Proceedings: $3^{\text {rd }}$ international symposium. Kranjska Gora: Univerza na Primorskem, Znanstveno-raziskovalno središče Koper.

Tremblay, L., Boudreau-Lariviere, C., \& Cimon-Lambert, K. (2012). Promoting physical activity in preschoolers: A review of the guidelines, barriers, and facilitators for implementation of policies and practices. Canadian Psychology, 53, 280-290.

Troiano, R.P., Berrigan, D., Dodd, K.W., Mâsse, L.C., Tilert, T., \& Mcdowell, M. (2008). Physical activity in the United States measured by accelerometer. Medicine and Science in Sports and Exercise, 40(1), 181-188.

Van der Horst, K., Paw, M.J., Twisk, J.W., \& Van Mechelen, W. (2007). A brief review on correlates of physical activity and sedentariness in youth. Medicine and Science in Sports and Exercise, 39(8), 1241-1250.

Veitch, J., Hume, J., Salmon, D., Crawford, D., \& Ball, K. (2011). What helps children to be more active and less sedentary? Perceptions of mothers living in disadvantaged neighbourhoods. Child: Care, Health and Development, 39(1), 94-102.

Verbestel, V., Van Cauwenberghe, E., De Coen, V., Maes, L., De Bourdeaudhuij, I., \& Cardon, G. (2011). Within- and between-day variability of objectively measured physical activity in preschoolers. Pediatric Exercise Science, 23(3), 366-378.

Videmšek, M., Videmšek, P., Štihec, J., \& Karpljuk, D. (2004). Sports activity and eating habits of 14 year-old male and female pupils. Kinesiologia Slovenica, 10(2), 65-77.

Volmut, T. (2014). Z merilnikom pospeška izmerjena gibalna/športna aktivnost mlajših otrok in analiza izbranih intervencij. [Physical/sports activity of young children as measured by accelerometer and analysis of selected interventions. In Slovenian.] (Unpublished doctoral dissertation, University of Primorska). Koper: Pedagoška fakulteta.

Volmut, T., Pišot, R., \& Šimunič, B. (2013). Objectively measured physical activity in children aged 5 to 8 years. Zdravstveno varstvo, 52(1), 9-18.

Welk, G.J., Wood, K., \& Morss, G. (2003). Parental influences on physical activity in children: An exploration of potential mechanisms. Pediatric Exercise Science, 15(1), 19-33.

Wennberg, P., Gustafsson, P.E., Dunstan, D.W., Wennberg, M., \& Hammarström, A. (2013). Television viewing and low leisure-time physical activity in adolescence independently predict the metabolic syndrome in mid-adulthood. Diabetes Care, 36, 2090-2097. 
Zurc, J. (2008). Biti najboljši. Pomen gibalne aktivnosti za otrokov razvoj in šolsko uspešnost. [Being the best. The importance of physical activity for child development and school performance. In Slovenian.] Radovljica: Didakta d. o. o.

Zurc, J. (2011). Gibalna aktivnost slovenskih otrok. [Physical activity of Slovenian children. In Slovenian.] In I. Avberšek Lužnik, B. Skela Savič \& K. Skinder Savić (Eds.), Etiologija in patologija debelosti: zbornik prispevkov z recenzijo (pp. 162-174). Jesenice: Visoka šola za zdravstveno nego Jesenice.

Zurc, J. (2012). Povezave med gibalno dejavnostjo in razvitostjo socialnih spretnosti pri otrocih. [Association between physical activity and level of social skills in children. In Slovenian.] Zdravniški vestnik: glasilo Slovenskega zdravniškega društva, 81(12), 847-860.

Submitted: October 7, 2015

Accepted: December 1, 2016

Published Online First: October 25, 2017

Correspondence to:

Tanja Jerina, Ph.D. student

Elementary School Polhov Gradec

Polhov Gradec, Slovenia

Phone: 0038640643245

E-mail: tanja.jerina@yahoo.com

\section{Acknowledgement}

We thank all the included children and their parents as well as principals and teachers for their participation in the study. For all the assistance provided we thank other researchers who helped in the design of the research and in performing the measurements.

The doctoral study, in the framework of which this contribution was created, was partly financed by the European Union, namely by the European Social Fund. The co-funding was performed in the framework of the Operational Programme Human Resources Development 2007-2013, Priority axis 1: Promoting entrepreneurship and adaptability; priority orientation 1.3: Scholarship schemes. 